\title{
EGG-LAYING AND FOAM-BEATING IN LEPTODACTYLUS FUSCUS (ANURA, LEPTODACTYLIDAE)
}

\author{
Júlio César de Oliveira Filho, Hugo Cardoso de Moura Costa and Úrsula Márcia Lobo Braga
}

Biota Neotropica v5 (n2) - http://www.biotaneotropica.org.br/v5n2/pt/abstract?short-communication+bn01305022005

\author{
Date Received 04/11/2005 \\ Revised 06/14/2005 \\ Accepted 07/01/2005
}

\begin{abstract}
Laboratório de Taxonomia, Ecologia Comportamental e Sistemática de Anuros Neotropicais, Instituto de Biologia, Universidade Federal de Uberlândia, Minas Gerais, Brazil.

E-mail:juliocesarfilho@yahoo.com.br
\end{abstract}

\begin{abstract}
Species of the Leptodactylus fuscus group lay their eggs in foam nests in underground chambers the males excavate. However, little is known about the interactions between males and females while egg-laying. We recorded egg-laying behavior in Leptodactylus fuscus. Observations were possible because the chambers walls were partially damaged (small holes). Within the chamber, the male holds the female in an axillary amplexus. In a typical sequence of egg-releasing/foambeating, the male makes alternate movements of legs in a series of kicks. After a bout of foam-beating the male releases the female removing his arms from her axils. When freed by the male, the female turned a little for a new bout of beating, being seized in an axillary amplexus again. In the species of Leptodactylus of the fuscus group the lack of thumb asperities and spines may be related to their terrestrial egg-laying behavior and to the stability the couples have within the chamber.
\end{abstract}

Key words: Leptodactylinae frogs, thumb asperities, Leptodactylus fuscus, amplexus, egg-laying behavior.

\section{Resumo}

As espécies de Leptodactylus do grupo fuscus põem ovos em ninhos de espuma no interior de câmaras subterrâneas escavadas pelos machos. Entretanto, pouco é conhecido sobre a interação entre machos e fêmeas enquanto ovipondo. Observamos o comportamento de oviposição em Leptodactylus fuscus. As observações foram possíveis por que as paredes das câmaras estavam parcialmente danificadas. Dentro da câmara, o macho segura a fêmea em amplexo axilar. Numa típica seqüência de oviposição/batimento de espuma, o macho faz movimentos alternados com as pernas, em uma série de chutes. Depois de um turno de batimento de espuma, o macho solta a fêmea removendo seus braços das axilas dela. Quando solta pelo macho, a fêmea gira um pouco para um novo turno de batimento, sendo abraçada nas axilas novamente. Nas espécies de Leptodactylus do grupo fuscus, a ausência de asperosidades nupciais e espinhos no polegar pode estar relacionada ao comportamento de ovipor em ambiente terrestre e a estabilidade que o casal tem dentro da câmara.

Palavras-chave: Anuros leptodactilíneos, asperosidades nupciais, Leptodactylus fuscus, amplexo, postura de ovos, comportamento oviposição.

http://www.biotaneotropica.org.br 


\section{Introduction}

Species of the Leptodactylus fuscus (Schneider 1799) group lay their eggs in foam nests in underground chambers the males excavate (Cei 1949, Martins 1998, Giaretta \& Kokubum 2004). Because the egg-laying and foam-beating behaviors are performed within the chamber, little is known about the interactions between males and females while egglaying. Amplexus was described for $L$. bufonius (Boulenger 1894) (Cei 1949), but details on spawning are unknown for any species of the group. In L fuscus, the chamber is built at margins of water bodies and has an entrance tunnel (Martins 1998, Giaretta \& Kokubum 2004). Here we describe behaviors performed by males and females of $L$. fuscus while spawning.

\section{Material and Methods}

On two occasions (Nov. 2004; 22:00-01:00h) we observed egg-laying behavior in Leptodactylus fuscus. Observations were made in a temporary pond (18m length x $6 \mathrm{~m}$ width) in the municipality of Uberlândia (Minas Gerais, Brazil). Observations were possible because, in both cases, the chamber walls were partially damaged, with 1-2 cm diameter holes on the walls. The couples were observed by flashlights. Behaviors within the chamber were observed about one hour in each instance.

\section{Results and Discussion}

Within the chamber, the male Leptodactylus fuscus holds the female in axillary amplexus. In a typical sequence of egg-releasing/foam-beating, the male makes alternate movements of legs in a series of kicks; a complete sequence of leg movement taking about two seconds. This pattern of alternate movements of males' legs resembles that described for Physalaemus pustulosus (Cope 1864) and P. ephippifer (Shreve 1941) (Heyer \& Rand 1977, Hold 1990). After a bout of foam-beating the male releases the female by removing his arms from her axils. After releasing the female, the male may pass his arms over his own head. When freed by the male, the female turned a little for a new bout, being seized in an axillary amplexus again. Axillary amplexus within the chamber has been described for $L$. bufonius (Cei 1949), but not other details on egg-laying was provided.

Thumb asperities or thumb spines are widespread in adult male leptodactyline frogs; but the species of Leptodactylus of the fuscus group and those of Adenomera, Lithodytes and Hydrolaetare have no such structures (Lynch 1971, Souza \& Haddad 2003). We suggest that in the species of Leptodactylus of the fuscus group the lack of asperities and spines may be related to their terrestrial egg-laying behavior (Duellman \& Trueb 1994) and to the stability the couples have within the chamber.

\section{Acknowledgements}

We thank to Ariovaldo A. Giaretta and Stanley Rand for critically read the draft.

\section{References}

CEI, J.M. 1949. Costumbres nupciales y reproduccion de un batracio caracteristico chaqueño (Leptodactylus bufonius Boul.). Acta Zool. Lilloana. 8:105-110.

DUELLMAN, W.E. \& TRUEB, L. 1994. Biology of Amphibians. 1ed. McGraw-Hill Press, New York.

GIARETTA, A.A. \& KOKUBUM, M.N.C. 2004. Reproductive ecology of Leptodactylus furnarius Sazima \& Bokermann, 1978, a frog that lays eggs in underground chambers (Anura: Leptodactylidae). Herpetozoa. 16(3/ 4):115-126.

HEYER, W.R \& RAND, A.S. 1977. Foam nest construction in the leptodactylid frog Leptodactylus pentadactylus and Physalaemus pustulosus. (Amphibia, Anura, Leptodactylidae). J. Herpol. 11:225-228.

HÖLD, W. 1990. An analysis of foam nest construction on the neotropical frog Physalaemus ephippifer. Copeia. 2:547-554.

LYNCH, J.D. 1971. Evolutionary Relationships, Osteology, and Zoogeography of Leptodactyloid Frogs. University of Kansas Printing Service, Kansas.

MARTINS, M. 1988. Biologia reprodutiva de Leptodactylus fuscus em Boa Vista, Roraima (Amphibia: Anura). Rev. Bras. Biol. 48(4):969-977.

SOUZA, M.B. \& HADDAD, C.F.B. 2003. Redescription and reevaluation of the generic status of Leptodactylus dantasi (Amphibia, Anura, Leptodactylidae) and description of its unusual advertisement call. J. Herpetol. 37(3):490-497.

Title: Egg-laying And Foam-beating In Leptodactylus Fuscus (Anura, Leptodactylidae)

Authors: Júlio César de Oliveira Filho, Hugo Cardoso de Moura Costa and Úrsula Márcia Lobo Braga

Biota Neotropica, Vol. 5 ( number 2): 2005

http://www.biotaneotropica.org.br/v5n2/pt/ abstract?short-communication+bn01305022005

Date Received 04/11/2005 - Revised 06/14/2005

Accepted 07/01/2005

ISSN 1676-0611 